\title{
Religião e cultura: um diálogo teológico sobre a Reforma protestante a partir de Martinho Lutero e Paul Tillich
}

\author{
Danjone Regina Meira*
}

\begin{abstract}
RESUMO
Este artigo busca apresentar algumas considerações teológicas e filosóficas sobre a interface religião e cultura na dimensão do acontecimento da Reforma protestante, especialmente, a partir do pensamento teológico de Martinho Lutero e Paul Tillich. Nessa perspectiva, busca-se ressaltar algumas características da Reforma Protestante a partir das obras de Paul Tillich Teologia sistemática (1951-1963), História do pensamento cristão (1988) e Teologia da cultura (1959) em diálogo com a obra 95 teses sobre as indulgências (1517) e Disputatio de Homine (1536) de Lutero. Palavras-chave: religião; cultura; Reforma Protestante; Lutero; Tillich.

\section{RELIGION AND CULTURE: A THEOLOGICAL DIALOGUE ON THE PROTESTANT REFORMATION ON MARTIN LUTHER AND PAUL TILLICH}

\begin{abstract}
This paper presents some theological and philosophical considerations about the interface between religion and culture in the dimension of the Protestant Reformation event, especially on the theological thought of Martin Luther and Paul Tillich. From this perspective, it highlights some characteristics of the Protestant Reformation from the works of Paul Tillich Systematic Theology (1951-1963), A History of Christian Thought
\end{abstract}

* Pós-doutoranda em Filosofia na Faculdade de Filosofia, Letras e Ciências Humanas (FFLCH) da Universidade de São Paulo - USP. Doutora em Filosofia pela Universidade de São Paulo - USP. Mestre em Ciências da Religião pela Universidade do Estado do Pará - UEPA. Bacharel em Teologia pela Faculdade Teológica Batista Equatorial - FATEBE. Bacharel em Direito pelo Centro Universitário das Faculdades Metropolitanas Unidas - FMU. E-mail: danjonemeira@hotmail.com Currículo Lattes: http://lattes.cnpq. br/3086975306258305. 
(1988) and Theology of Culture (1959) in dialogue with the work The 95 Theses (1517) and the work Disputatio de Homine (1536) by Luther. Keywords: Religion; Culture; Protestant Reformation; Luther; Tillich.

\section{Introdução}

A Reforma protestante (1517) pode ser demonstrada, essencialmente, na seguinte expressão: "a fé justifica-se sem nenhuma obra", que pode ser compreendida como "[...] o princípio da justificação pela graça mediante a fé" (TILLICH, 2005, p. 668). O que o acontecimento da Reforma protestante vem a representar na história indica as transformações culturais e religiosas pelas quais o pensamento ocidental estava passando. Especificamente, voltando-se a atenção para a teologia de Martinho Lutero, pode-se observar que, em certa medida, as próprias raízes do fenômeno da renascença estavam presentes em sua construção teológica. Por isso, no primeiro tópico deste artigo se abordará sobre os fundamentos do século XVI, sendo intitulado: "Lutero e o contexto espiritual da sua época". Neste tópico se buscará ressaltar alguns aspectos do contexto histórico e espiritual em que surgiu a Reforma protestante, bem como se destacará a própria relação da religião e da cultura nesse contexto espiritual.

A tarefa de refletir sobre alguns aspectos da Reforma protestante permanece um desafio por ser um fenômeno religioso que vai para além de sua época. A análise da Reforma protestante é de suma importância não somente para os estudos da religião como para os estudos teológicos e filosóficos. O enigma do princípio protestante permanece e deve se colocar diante deste fenômeno religioso reconhecendo a necessidade de uma reflexão constante. A partir da análise do pensamento de Paul Tillich, pode-se pensar sobre a história espiritual da humanidade e, nesse sentido, acerca do contexto do fenômeno da Reforma protestante e seus pilares fundamentais.

Tendo a Reforma protestante surgido em 1517 num tempo de crise de fundamentos no pensamento ocidental, pensar o fenômeno da Reforma requer considerar, sobretudo, o horizonte histórico. Conforme se enfatizará, é tarefa da teologia pensar a história. A teologia deve sempre pensar os fenômenos no horizonte da história. Haja vista que, de acordo com Tillich: “a dimensão histórica está presente em todos 
os âmbitos da vida" (TILLICH, 2005, p. 784). Já no segundo momento deste artigo se analisará a interface "fé e existência" no pensamento de Martinho Lutero, buscando estabelecer um diálogo com a análise teológica de Tillich.

\section{Lutero e o contexto espiritual da sua época.}

No cenário histórico do século XIV e dos séculos seguintes se destacou na Itália o prisma hermenêutico de considerar a Antiguidade clássica como a perspectiva preponderante para a cultura. Conforme Reale:

Ora, a partir sobretudo da metade do 300 , e depois de modo representado sempre crescente nos dois séculos sucessivos, desenvolveu-se na Itália justamente uma tendência a atribuir valor muito grande aos estudos das litterae humanae e a considerar a antiguidade clássica, grega e latina, como um paradigma e um ponto de referência para as atividades espirituais e a cultura em geral (REALE, 2004, p.3).

No final do século XIV, especialmente, o fenômeno do humanismo (século XIV ao XVI), foi considerado como uma tendência. Mas, para além disso, o humanismo revela-se como um novo sentido acerca do homem e de seus problemas, celebrando a "dignidade do ser humano" como um "ser de extrema importância". Especificamente, o humanismo contribuiu para o retorno às origens. As obras de Aristóteles, por exemplo, eram lidas na língua original. O cultivo do estudo da Antiguidade clássica e das línguas originais marcou aquela era.

Vindo a atingir o seu ápice no século XV, o humanismo demonstrou-se nas variadas expressões artísticas, tais como: a pintura, a escultura e a poesia; denotando a perspectiva da liberdade. Em face disso, entende-se que o humanismo e a renascença podem ser considerados faces de um único fenômeno: o renascimento do espírito humano. Pode-se ainda afirmar que as consequências da renascença foram o despertar para o indivíduo e a questão da liberdade que se refletiriam na era da luz ou Idade Moderna (1453-1789).

Nesse horizonte hermenêutico, destaca-se o surgimento da Reforma protestante que teve o seu ápice no século XVI, no entanto, é importante enfatizar que os seus aspectos basilares já vinham sendo forjados desde o século anterior. No que concerne a isso, segundo o teólogo da cultura 
Paul Tillich (1886-1965): "Lutero conservava certos elementos nominalistas e humanistas em seu ensino" (TILLICH, 2000, p.241). Assim sendo, pode-se compreender o cenário deste século também como um cenário de crise e de transição para a época moderna. O cenário de crise demonstrava-se no contexto político, social, econômico e educacional no século XVI. O que se pode notar, sobretudo, é a presença de uma crise no pensamento que buscava superar as ideias do pensamento medieval e romper completamente com a cosmovisão da Idade Média (século $\mathrm{V}$ ao XV). A superação do pensamento medieval evidenciava-se como uma transição para um pensamento mais crítico e essencial.

Refletindo sobre a sua época no cenário espiritual da modernidade, o filósofo alemão Immanuel Kant (1724-1804) em sua obra "O que é esclarecimento?" (Was ist Aufklärung? 1783) destaca:

Esclarecimento ["Aufklärung"] é a saída do homem de sua menoridade, da qual ele próprio é culpado. A menoridade é a incapacidade de fazer uso de seu entendimento sem a direção de outro indivíduo (KANT, 1985, p.100).

É um grande esforço do pensamento realizar o salto para a marcha do pensamento essencial. Um salto que requer coragem e espírito ousado para se elevar da menoridade para a maioridade. Nessa perspectiva, a Idade Média pode ser vista como uma era em que prevalecia a menoridade. A passagem para a maioridade se demonstra, de modo especial, a partir da época da luz: a Idade Moderna. Mas, como se caracteriza a maioridade segundo o pensador alemão Kant? A maioridade se revela no uso público da razão que "[...] deve ser sempre livre e só ele pode realizar o esclarecimento ["Aufklärung"] entre os homens" (KANT, 1985, p.104).

É importante enfatizar que o uso público da razão pode ser empregado por qualquer pessoa sábia em sua fala diante do público. Dessa forma, o próprio sacerdote ou o ser religioso ao ter alcançado o espírito esclarecido detêm a liberdade e o dever de trazer ao público o conhecimento de suas ideias. Ele deve anunciar "[...] o que há de errôneo naquele credo, e expor suas propostas no sentido da melhor instituição da essência da religião e da Igreja" (KANT, 1985, p.106). O sacerdote ao fazer o uso público da razão, o faz como sábio, e não 
como sacerdote, visto que anuncia ao verdadeiro público: o mundo. Quando o sacerdote faz o uso privado da razão está realizando o uso para a igreja. Por essa razão, requer-se coragem e esforço para se elevar para a maioridade. As épocas do mundo estão sempre avançando no caminho do esclarecimento. O esclarecimento deve abranger todas as esferas da vida humana: a lei, o direito, o governo, a economia e o espírito humano como um todo.

“[...] Vivemos em uma época de esclarecimento ['Aufklärung']" (KANT, 1985, p.112), assim Kant define a época moderna em que ele se encontra. As obras do pensador são um marco na história e retratam que cada vez mais se deve avançar no esclarecimento. É uma época do esclarecimento em que há a superação daquela menoridade imposta na Idade Média, em que aos seres humanos era imposta a própria religião. Com a superação da menoridade imposta, o ser humano tem a liberdade de pensar e dizer sobre a religião. A humanidade foi liberta da menoridade por parte do governo. Foi dado "[...] a cada homem a liberdade de utilizar sua própria razão em todas as questões da consciência moral" (KANT, 1985, p.112). Isso caracteriza o espírito de liberdade dessa época.

Na religião há o interesse de se manter a tutela sobre os respectivos súditos. Esse tipo de menoridade, segundo Kant, “[...] é de todas a mais prejudicial e a mais desonrosa" (KANT, 1985, p.114). Desse modo, a passagem da menoridade para a maioridade acontece no próprio horizonte da religião.

Se no século XVIII, Kant exerce a sua vocação ao pensamento livre inaugurando a sua obra "O que é o esclarecimento" no cenário da era moderna, bem antes, já no século XVI, Martinho Lutero (1483-1546) apresentava em suas obras o que pode ser refletido a partir do dito de Kant como uma "[...] corajosa crítica do estado de coisas existente" (KANT, 1985, p.114).

No panorama do século XVI, o problema do "logos" (termo grego podendo vir a ser traduzido como razão ou palavra) e o problema da "alétheia" (termo grego empregado para indicar a verdade) ainda permeava as questões principais deste século, mas, acima de tudo, relacionado com a pergunta pelo ser do homem e a sua liberdade. Nesse sentido, a tradução para o latim dos termos gregos "logos" e "alétheia", 
respectivamente, como "ratio" e "veritas" teria repercutido de modo crucial, especialmente, no século XVI, em que se destaca a pergunta pelo sentido do ser humano. No que concerne à Reforma protestante, a reflexão sobre o "logos" e a "alétheia" se demonstrava na pergunta crucial pela essência da igreja (ekklesía) e o seu papel como representante da palavra (logos) para a humanidade.

A interpretação da "ekklesía" por parte do sistema romano é diferente da compreensão de Lutero do que seja a igreja segundo as "Sagradas Letras". Na época medieval há uma relação fundamental entre a salvação, a vida eterna e os sacramentos. A igreja estabelecia uma estrutura de sacramentos como a base do pensamento cristão.

Conforme assinala Tillich:

pretende dar ao homem a bem-aventurança eterna salvando-o da punição eterna. As alternativas são o eterno sofrimento no inferno ou o eterno prazer no céu. Alcança-se tal propósito por meio dos sacramentos, nos quais a graça mágica e divina fica de um lado, e a liberdade moral e produtora de méritos, do outro - a graça mágica é completada pela lei ativa, e a lei ativa é completada pela graça mágica (TILLICH, 2000, p.228).

Ao analisar as características do período histórico do final da Idade Média, Tillich ressalta um problema existencial: a forma de compreensão do sentido da graça e a insuficiência das obras de ascese, em face disso "[...] havia muita ansiedade no final da Idade Média" (TILLICH, 2000, p.228). Nessa perspectiva, o distanciamento da compreensão da essência da igreja fora percebido por Martinho Lutero de modo preponderante. Pode-se entender a ação das 95 teses pregadas em 1517 por Lutero na igreja de Wittenberg enquanto o anunciar do esquecimento da essência da igreja e o anunciar do desvio da essência da palavra realizado pela igreja durante aqueles séculos na Idade Média. Irrompe um novo pensamento na teologia de Lutero em face da cultura medieval.

As 95 teses se revelam como o marco da crise do pensamento medieval que já vinha sendo forjada em séculos passados, mas, com a ação de Lutero, como precursor da Reforma protestante, se mostram como o passo principal para o surgimento dela. Reforma esta que é uma reforma de pensamento, uma correção de visão, como pode-se perceber nos escritos de Lutero. Desse modo, a influência da renascença nos 
escritos de Lutero pode ser compreendida como a volta aos princípios, mas, aos princípios da fé cristã. Afirma Reale:

A Renascença representou grandioso fenômeno de "regeneração" e de "reforma" espiritual, em que a volta sobre a volta aos antigos significou revivescência das origens, 'retorno aos antigos princípios autênticos', e a imitação dos antigos revelou-se como o caminho mais eficaz para recriar e regenerar a si mesmos (REALE, 2004, p.9).

No que concerne a isto, segundo Tillich (2000, p.241): "Na Renascença, a Bíblia é a fonte da religião verdadeira [...]". Lutero anuncia também o velamento do sentido essencial da verdade apresentado pela igreja naquela era. $\mathrm{O}$ velamento ou esquecimento da essência da verdade se demonstrava nas práticas religiosas da igreja que, consequentemente, apontava para o esquecimento da essência da igreja. Isto se destaca, sobretudo, na questão das indulgências presentes na igreja católica. Mas, antes desse artigo deter-se na questão crucial das indulgências, faz-se necessário refletir acerca do contexto em que a Reforma protestante teve o seu surgimento.

O caminho para a Reforma protestante teve o seu passo principal com as 95 teses de Lutero, indicando que tal ação não somente era religiosa, mas, repercutiria nos parâmetros sociais e políticos daquela época em diante. Ao se buscar pensar no termo alemão "Geist" (traduzido para o português como espírito), pode-se compreender que este também seria um termo apropriado para indicar a cultura enquanto espírito daquela época. Com isso, as 95 teses representariam também o espírito daquele momento que buscava evidenciar um distanciamento do pensar medieval a partir da busca de instauração de um pensar crítico. Nessa perspectiva, a obra "História do pensamento cristão" (1988) de Paul Tillich busca refletir sobre o pensamento da tradição cristão, em que a história desvela as características primordiais da Reforma protestante. Isso pode ser percebido na teologia de Tillich mediante a relação entre a compreensão da história e a própria tarefa da teologia. Conforme Tillich: "a história é a dimensão todo-abrangente da vida" (TILLICH, 2005, p.783).

A necessidade de se compreender a história faz parte da tarefa essencial do pensamento teológico. Também faz parte da tarefa primor- 
dial da teologia entender o que é a cultura. Isso dá à luz os problemas inerentes àquele contexto. Dessa forma, o problema da fé ao longo da história foi representado pela Reforma protestante que questionou o papel não somente da igreja, mas da própria teologia na totalidade da história, bem como, nas próprias expressões culturais do espírito humano. Na Idade Média, a arte, a pintura, a escultura, a poesia expressavam também como a igreja se comportava perante a fé. Este momento da história também ocasionou em problemas existenciais, como por exemplo, a ansiedade. Segundo Tillich (2000, p.228-229): "a arte do período expressa intensamente essa ansiedade". A obra de Hieronymus Bosch "O julgamento final”, inaugurada cerca de 1482 a $1516^{1}$, por exemplo, expressa as preocupações que predominavam na era medieval:

A obra de arte de Bosch desvela o espírito da época. Religião e cultura se inter-relacionam essencialmente na pintura: "O julgamento final". Nesse sentido, é importante destacar que, embora o pintor ressalte as temáticas com um certo aspecto satírico, pode-se notar, de maneira especial, a mentalidade da época na representação dos pecados e das preocupações religiosas presentes no contexto do homem medieval.

No que concerne a isto, o teólogo da cultura Paul Tillich enfatiza em seu escrito "Teologia da cultura" (1959) que a religião também se desvela na arte. O teólogo da cultura Tillich realiza uma interpretação da arte a partir da análise da relação entre a religião e a cultura. Tillich considera que o incondicionado está presente em toda a cultura. Torna-se, então, papel da teologia enquanto teologia da cultura refletir sobre as manifestações do incondicionado em uma dada situação. A obra de arte reflete como cada cultura entende a manifestação do incondicionado. Desse modo, a obra de arte também pode ser a expressão da cultura que "[...] acentua a finitude humana, a morte, mas acima de tudo, a separação de nosso ser verdadeiro e a escravidão às forças demoníacas - forças de autodestruição" (TILLICH, 2009, p.113).

www.statenvertaling.net: Home: Info, Domínio público, https://commons.wikimedia. org/w/index.php?curid $=4593502$

https://pt.wikipedia.org/wiki/Hieronymus_Bosch\#/media/Ficheiro:Last_judgement_ Bosch.jpg 
Partindo dessa análise de Tillich, entende-se que a obra de Bosch: "O julgamento final" é uma expressão artística da situação existencial do ser humano na época medieval.

Bosch apresenta diante da sociedade, com grande ênfase, as questões existenciais do ser humano num mundo repleto de culpa, ansiedade e desespero. Dessa forma, o estilo artístico de Bosch busca caracterizar o espírito de toda uma época.

Cada obra de arte apresenta três elementos: tema, forma e estilo. Especificamente, o elemento: forma, está relacionado aos aspectos estruturais do ser, fundamentando a singularidade da coisa. Revela o próprio poder expressivo da obra de arte. De acordo com Tillich:

a criação artística é determinada pela forma, que usa materiais especiais como som, palavras, pedras e cores, elevando-os à condição de obra que existe por si mesma. Por causa disso, a forma é o elemento ontologicamente decisivo em qualquer criação artística - bem como em qualquer outra criação. Mas a forma sempre é qualificada pelo terceiro elemento que chamamos de estilo (TILLICH, 2009, p. 114-115).

Nesse sentido, o estilo caracteriza a obra de arte em seu período determinado de modo singular. A obra de arte existe tendo como ponto de partida o elemento ontológico: forma. Cada obra de arte expressa a interpretação existencial do ser humano em resposta à pergunta da preocupação última da existência. Assim sendo, a obra de arte de Bosch desvela a preocupação última da vida humana na época em que surge.

Conforme Tillich destaca em sua obra "Teologia da cultura" todo o artista "[...] sempre demonstrará em seu estilo sua preocupação suprema, que será a mesma de seu grupo e de seu tempo. Não conseguirá escapar da religião mesmo se a rejeitar" (TILLICH, 2009, p. 115-116). Cada obra de arte indica algo da época em que ela irrompeu. Nessa perspectiva, a religião se faz presente em toda a cultura, visto que, em toda era se faz presente a preocupação suprema da vida humana. Sendo assim, a obra "O julgamento final" de Bosch desvela, portanto, a auto-compreensão do ser humano na época.

Uma das perguntas importantes de Tillich que cabe, nesse momento, enfatizar é: "Será que alguns estilos expressam melhor do que outros a temática religiosa?" (TILLICH, 2009, p.118). Embora, o estilo 
expressionista seja considerado como aquele que melhor expressa a temática religiosa no pensamento de Tillich, é relevante destacar que não há obra de arte que não expresse a preocupação última, visto que, o incondicionado permeia toda as criações culturais.

A presença da preocupação última da existência ou o incondicionado na obra de arte "O julgamento final" pode ser compreendido do seguinte modo:

O absoluto está presente, ainda, nas experiências da realidade que mostram o seu lado negativo, feio e auto-destrutivo. Está presente como o divino-demoníaco para julgar o contexto de tudo o que existe. (TILLICH, 2009, p. 118).

O significado religioso presente na obra "O julgamento final" de Bosch retrata, então, características importantes do pensamento da Idade Média. Segundo Ribeiro, “[...] certo é que nenhum outro pintor retratou de forma tão perturbadora os medos que pairavam sobre a humanidade no crepúsculo da Idade Média” (RIBEIRO, 2015, p.22). A análise da cultura e da religião proporciona uma luz à problemática teológica em face da situação. A questão da Reforma protestante pode ser entendida como um ponto de referência de que a mensagem deve ser anunciada em face de toda e qualquer situação.

Diante desse panorama se instaura, então, a pergunta: o que caracteriza a Reforma protestante? Conforme Tillich (2000, p.227): “o ponto decisivo da Reforma, e da história da igreja em geral, foi a experiência de um monge agostiniano em sua cela monástica - Martinho Lutero". Martinho Lutero apresenta em sua teologia da Reforma uma teologia da ruptura, que busca romper com o modo de pensar e fazer teológico do sistema romano. Desse modo, Lutero inaugura, assim, na época da renascença, a sua teologia que pode ser caracterizada como teologia da Reforma. Nessa perspectiva, o pensamento de Lutero e o seu modo de fazer teológico foi demonstrado, especialmente, em seu ato revolucionário nas 95 teses pregadas na catedral de Wittenberg. Fora um ato revolucionário em face do sistema romano, uma ruptura, que ocasionou a transformação teológica da época e para além dela. Nesse sentido, é importante enfatizar que Tillich o define como "[...] um dos poucos profetas da igreja cristã” (TILLICH, 2000, p.227). 
Lutero volta-se para às "Sagradas Letras" buscando anunciar o cristianismo puro, que renasce na Reforma. Nesse sentido, a análise de Tillich acerca da teologia da Reforma em Lutero, busca abordá-la não sob o viés do precursor do luteranismo, mas, como o profeta que desenvolveu a ruptura do sistema romano. Enquanto teólogo da fronteira, Tillich define o pensar de Lutero como um pensar transformador que tem como fenômeno a ruptura com a compreensão da religião católica romana acerca da fé cristã.

A cultura medieval apresentava em sua essência a religião, especificamente, a religião católica romana como predominante na espiritualidade daquele período histórico da humanidade. Com a ruptura inaugurada na teologia de Lutero, há a busca de superação do cristianismo que se demonstra na religião católica romana. Havendo também uma busca de superação do espírito daquela época, ocasionando na própria superação da cultura medieval. Surge, então, uma outra religião. Nesse horizonte, conforme Tillich, religião seria um "tipo de relacionamento pessoal entre homem e Deus - entre o homem e Deus e entre Deus e o homem" (TILLICH, 2000, p.227).

A Reforma protestante que tem como marco o pensamento e ação de Lutero acaba por inaugurar uma nova compreensão de religião. Inaugura-se no cenário espiritual do século XVI a relação protestante com Deus. A compreensão religiosa de Lutero irrompe contra um sistema cultural imposto pela igreja daquela época e constituinte do sistema romano. A compreensão da relação do homem para com Deus era ditada pela igreja do sistema romano sob uma estrutura de sacramentos que causavam ainda mais ansiedade na humanidade.

Uma quantidade de sacramentos deveria ser seguida como máxima. No entanto, de acordo com Tillich (2000, p.229): "a Reforma redescobriu as categorias incondicionais da Bíblia".

Nesse sentido, vale destacar que para o pensador Battista Mondin:

[...] a Reforma Protestante foi antes e acima de tudo um acontecimento religioso. Em consequência disso, ela deve ser estudada e julgada segundo critérios religiosos, mais precisamente, segundo os critérios da fé cristã, cujo espírito original a Reforma se propunha restabelecer (MONDIN, 1981, p.41). 
Especialmente sobre a teologia de Lutero, pode-se observar nos seus escritos, vida e perspectivas cristológicas, eclesiológicas, soteriológicas e antropológicas, as características das transformações históricas que irromperam no espírito da época. Há uma preocupação substancial em seu pensamento de se voltar para a essência do "logos" e dessa forma, o espírito deveria corresponder com a letra da palavra. Assim como, a essência do homem e a essência da igreja seriam resgatadas. No entanto, isso somente seria possível tendo como ponto de partida as Escrituras Sagradas, especificamente, o modo de ser do Evangelho primitivo e, também levando em consideração algumas características da teologia paulina. De acordo com Tillich, para Lutero: "o critério fundamental para a compreensão do cristianismo era a mensagem do Evangelho" (TILLICH, 2000, p.233).

Lutero se volta para as epístolas paulinas com o propósito de evidenciar a soberania de Deus e a relação do homem com a justificação mediante a fé. É importante ressaltar que a teologia de Lutero recebe influência da teologia paulina, assinala Tillich (2000, p.230): "Lutero acreditava que reproduzia o ensinamento do Novo Testamento, especialmente de Paulo". Ele recebe da teologia paulina a doutrina da justificação mediante a fé, que se destaca como a ação de Paulo contra o legalismo. Nesse sentido, pode-se afirmar que o que a Reforma representa essencialmente é a busca de uma interpretação genuína da cristologia, da eclesiologia e da soteriologia.

Com o olhar para o evento da salvação em Cristo, Lutero pontua que a igreja deve ser cristocêntrica. A eclesiologia também emanaria da cristologia. Conforme assinala o teólogo Tillich (2000, p.239), “[...] a teologia da Reforma difere da teologia dos movimentos evangélicos radicais tem a ver com o significado da cruz". Visto que, de acordo com Tillich (2000, p.239): "para os reformadores, a cruz é o evento objetivo da salvação e não mera experiência pessoal da criatura humana".

No pensar de Lutero a soberania divina é enfatizada em face do homem. Assim, Lutero destaca a relação primordial entre a soberania de Deus e a salvação pela fé, trazendo para o ambiente de indulgências o anunciar sobre a essência da doutrina da salvação (soteriologia) que é o evento Cristo. Nessa perspectiva, é a partir de Lutero que os conceitos da fé, da salvação, da igreja e do cristão são renovados, alcançando 
um teor de revolução. Em Lutero a igreja também é renovada sob o viés da ética.

O teólogo Tillich enfatiza que a teologia de Lutero buscava em face da cultura medieval instaurar uma compreensão essencial da salvação. Nesse sentido, afirma Tillich (2000, p.239): "Lutero e os demais reformadores procuraram mostrar que o homem está longe de Deus". A teologia da Reforma procura, desse modo, falar sobre a salvação a partir do evento Cristo, a fim de que com base na Palavra de Deus, o ser humano possa se aproximar de Deus.

Acerca do aspecto cristocêntrico no pensar de Lutero, pode-se observar tal aspecto quando ele afirma nas teses 94 e 95: "94. Deve-se exortar os cristãos a que se esforcem por seguir a Cristo, seu cabeça, por meio de penas, mortes e inferno; 95. E, assim, a que confiem que entrarão no céu por meio de muitas tribulações, e não por meio de uma [ilusória] segurança de paz" (LUTERO, 2017, p.49). Mondin ressalta que Lutero apresenta uma: "concepção nominalista do conceito de Deus e uma visão pessimista do homem" (MONDIN, 1981, p.107).

À luz disso, enfatiza-se que os fundamentos e as questões que impulsionaram a Reforma protestante no século XVI se destacam como tentativas de rupturas com o pensamento escolástico medieval. Tentativas de rupturas que desde o século XIV ressaltavam eventos que encontrariam o seu ápice na Reforma, como um acontecimento revolucionário na história. Como se assinalou, Lutero empreendeu uma reviravolta na religião. O fundamento da Reforma apresentado no significado da famosa frase, sola fide, destaca, portanto, uma compreensão essencial acerca da essência da igreja: Cristo como o centro. Desse modo, conforme reflete Tillich acerca da dimensão da fé no pensar de Lutero: "fé significa nada mais do que a aceitação da graça" (TILLICH, 2000, p.235).

O século XVI ao representar a busca de ruptura com o pensamento supersticioso da tradição medieval e escolástica, busca apresentar, de acordo com Tillich (2000, p.233): "a compreensão reformada do relacionamento do homem com Deus abolia o ponto de vista medieval". Todas as tentativas de rupturas se demonstram como transformações no interior da história que repercutiriam na necessidade imperiosa de uma nova compreensão do cerne da religião. Não se havia o propósito de se criar uma igreja, mas de resgatar a essência da igreja. Nesse 
sentido, a Reforma também indica uma transformação religiosa que já estava sendo ensaiada no interior da religião católica. A igreja católica passava por uma grave crise, que pode ser entendida como a falta de fundamento. Por isso, a Reforma pode ser reconhecida como um ato revolucionário religioso. Mas, vai para além disso, atingindo o âmbito cultural europeu em sua totalidade.

Ao se voltar para a história espiritual do pensar cristão, é importante ressaltar que a compreensão da essência da história também se coloca como tarefa para a teologia da cultura de Paul Tillich. Também como questão para o pensar e fazer teológico. Por isso, se torna fundamental apresentar alguns aspectos sobre o que Tillich compreende acerca da essência da história e o método que ele emprega em face da sua análise cultural e teológica do pensar cristão. É importante destacar que Tillich compreende a história a partir da interpretação do termo grego "kairós" (que pode ser traduzido para a língua vernácula como 'tempo oportuno'). A essência da história é, desse modo, escatológica. Aponta para o futuro escatológico que se cumpre na revelação final e plena do reino de Deus.

Com essa compreensão da história tendo em consideração o "kairós", Tillich delimita a sua concepção histórica no seu sistema teológico. O seu estudo sobre o pensamento cristão remete ao seu próprio sistema teológico, o que ele compreende do que é a teologia e como ela é, do seu modo de pensar e fazer teológico que se consagra em sua tarefa. Pode-se afirmar que ao meditar sobre o pensamento cristão, Tillich considera também a sua perspectiva teológica da cultura. Nesse sentido, ao se voltar para a compreensão do pensamento cristão, ressalta-se que somente se pode compreender o pensamento cristão quando se considera que a mensagem kairótica é para a situação em um dado contexto cultural.

\section{Fé e existência}

A história deve ser considerada sob a perspectiva do "kairós" (o tempo oportuno). O acontecimento da Reforma se desvela no tempo oportuno. Mesmo em meio à crise que ainda se alastrava no cenário ocidental, verifica-se que o pensar de Lutero buscou superar a crise do sistema teológico medieval, que foi marcado pelo problema espiritual 
das indulgências, da insatisfação das obras para se alcançar a certeza da salvação.

Voltar à fonte do Evangelho fora fundamental para se instaurar a Reforma, que tem o seu fundamento em Cristo. Ela surge como um acontecimento que aponta para o próprio sentido da história: Cristo. Toda a realidade, desde então, sofreu transformações de fato. O que caracteriza a nova religião que irrompe com a Reforma protestante é o voltar para às Sagradas Escrituras, considerando a justificação da fé pela graça. A própria justificação é anterior à regeneração. Eis o aspecto paradoxal da compreensão da situação existencial segundo o ponto de vista da Reforma.

Trata-se de buscar compreender o significado originário do relacionamento de Deus com o homem e do homem com Deus. O fenômeno da Reforma descreve a luta de Lutero diante do sistema. Mas, vai para além disso, pode-se entender como uma luta perante as bases epistemológicas, ontológicas e teológicas da igreja medieval. Com a pergunta sobre a base da fé, Lutero está a perguntar pela estrutura originária do ser humano. A fé constitui o ser humano. O existir depende do relacionamento com Deus. Nesse sentido, é importante destacar a dimensão da fé no pensar de Lutero. É a relação pessoal do ser humano para com Deus que "Lutero chamava de 'fé"” (TILLICH, 2000, p.229). Essa compreensão surge essencialmente com a influência de Paulo sobre Lutero.

O sentido originário da igreja também emana da compreensão que se tem da fé. Mas, a fé está diretamente relacionada com o poder da graça. Lutero busca retomar o significado originário da fé a partir do Evangelho. O Evangelho segundo João seria analisado por Lutero de modo especial. A Reforma oferece, então, naquele cenário uma nova compreensão do próprio fenômeno religioso. Com isso, o discurso teológico nas obras de Lutero, consequentemente constrói uma nova visão de mundo. Isso constitui também o marco da Reforma. Esta nova percepção da vida naquele contexto se revela nas expressões e manifestações do ser humano. Tem-se o propósito de apreender um significado profundo da vida mesma fundamentando-se na revelação histórica da Bíblia.

Como se enfatizou, para Tillich, a experiência religiosa está presente na cultura, é a experiência com o incondicionado. Todo o ser humano 
é em sua essência um ser que instaura a pergunta pelo significado último da vida. Embora, a Reforma irrompa no cenário da modernidade, a nova religião veio a fortalecer o seu pensamento sobre a fé e a graça que repercutiram para além daquele século. Dessa forma, pode-se compreender que Lutero operou um pensar e o atuar muito bem solidificado que acabou por atingir a própria compreensão da existência humana. O ser humano depende sempre de Deus.

A dependência absoluta para com Deus descreve o sentido da justificação pela graça através da fé destacada por Lutero. A questão de Deus no pensar de Lutero é baseada nas Escrituras Sagradas, e enfatiza o aspecto cristocêntrico da teologia de Lutero. Toda a teologia de Lutero é cristocêntrica. Por ser um retorno às Sagradas Escrituras, por se basear no Evangelho de Cristo, Lutero contribuiu para o anúncio da comunhão espiritual de Deus com o ser humano para além dos ambientes eclesiásticos através da fé.

Lutero destaca em sua obra, segundo Tillich (2000, p.246): “[...] a grandeza de Deus, sua presença constante e, ao mesmo tempo, sua absoluta transcendência". É importante destacar que para Lutero, de acordo com Tillich (2000, p.246): “[...] todas as ordens e instituições naturais se plenificam com a presença de Deus, e assim, também, o processo histórico". Deus fala por meio da história. Ele fala no "kairós”. Segundo Tillich (2000, p.247): “[...] ninguém pode fazer nada fora desse momento certo".

Com o propósito de retorno a essência, a primeira tese de Martinho Lutero parte dos evangelhos sinóticos, especificamente, o evangelho de Mateus (4.17), enfatizando a relação entre existência, fé e penitência (no sentido de arrependimento). Segundo Lutero: "1. Quando o nosso Senhor e Mestre Jesus Cristo diz: "Arrependei-vos..." (Mt 4.17), ele quer que toda a vida dos que creem seja arrependimento" (LUTERO, 2017 , p.38). A própria existência cristã deveria refletir em seu fundamento a penitência. Mas, o que Lutero entendia por penitência?

A segunda tese vem aclarar o sentido da penitência, indicando que esta penitência não se refere à penitência do contexto do sacramento, relacionada à função sacerdotal. Nas palavras de Lutero: "2. Essa palavra de arrependimento não pode ser entendida como se referindo ao sacramento da penitência (isto é, à confissão e reparação) administrada 
pelos sacerdotes" (LUTERO, 2017, p.38). Através do conceito de fé, Lutero fundamenta a sua compreensão sobre a comunhão com Deus. A esse respeito, ressalta Tillich:

Dissolvia-se, assim, o sacramento da penitência, completamente, transformava-se em relação pessoal com Deus e com o próximo, contra o sistema mediador estabelecido para a obtenção da salvação das penas do inferno, do purgatório e mesmo da terra (TILLICH, 2000, p.233).

Como Lutero bem exemplifica na tese 36: “36. Todo cristão que se arrepende verdadeiramente recebe pleno perdão da pena e da culpa, mesmo sem carta de indulgência" (LUTERO, 2017, p.42). Lutero centralizava a sua crítica, segundo Tillich, em face dos "abusos relacionados com o sacramento da penitência” (TILLICH, 2000, p.231). Dá-se um novo significado ao sacramento. No pensamento de Lutero, a punição que o ser humano pode sofrer, de fato, é estar separado de Deus. Em face disso, na justificação pela graça mediante a fé o ser humano está unido com Deus. Nessa perspectiva, o fundamento da igreja é Cristo. Ele é "o sacramento da Palavra", segundo assinala Tillich (2000, p.251).

A questão da essência do homem é especialmente apresentada em seu escrito "Disputatio de homine" de $1536^{2}$. Lutero coloca face-a-face a "ratio" (fundamentalmente antropocêntrica) e a sua compreensão do "logos" e da fé baseada genuinamente na palavra das Escrituras sagradas. Para Tillich: "[...] Mas, além disso, Lutero interpretava as Escrituras em harmonia com a sua nova compreensão da relação do homem com Deus. Essa posição aparece em seu conceito da "Palavra de Deus"” (TILLICH, 2000, p.241).

Na primeira tese, Lutero assinala: "a filosofia, sapiência humana, define o homem como sendo animal racional, sensitivo, corpóreo" (LUTERO apud FERNANDES, 2018, p.389). A definição filosófica do ser do homem une ratio e antropos. O ser humano como ser racional é

2 FERNANDES, M. A. "Disputação acerca do Homem (Teses)", de Martinho Lutero. Revista de Filosofia Moderna e Contemporânea, [S. 1.], v. 5, n. 2, p. 389-392, 2018. DOI: 10.26512/rfmc.v5i2.12615. Disponível em: https://periodicos.unb.br/index.php/ fmc/article/view/12615 Acesso em: 16 ago. 2021. Disputação acerca do Homem (Teses). Martinho Lutero. Tradução. Marcos Aurélio Fernandes. Revista de Filosofia Moderna e Contemporânea, Brasília, v.5, n.2, dez. 2017, p. 389-392. 
uma perspectiva consagrada no humanismo e Lutero, embora, estando no século XVI, e sendo conhecedor das características renascentistas presentes em sua época, busca empregar o pensamento crítico para enfatizar a essência do ser humano à luz da Bíblia.

No pensamento de Lutero se destaca claramente que a definição do homem como animal não aponta para a dimensão espiritual do ser humano, mas somente destaca o seu caráter mortal. O pensador da Reforma se preocupa em destacar que a razão tem uma essência divina, ressaltando sua perspectiva teológica da criação. E que a partir da "imago Dei" o ser humano apresenta a razão terrena, como um homem de saber. Nesse sentido, na sexta tese ele anuncia: "e em virtude desse merecimento ela deve ser chamada diferença essencial, pela qual o homem é constituído na diferença em relação aos animais e outras coisas" (LUTERO apud FERNANDES, 2018, p.389). Assim sendo, o ser humano apresenta uma diferença ontológica diante dos demais entes, visto que, enquanto animal racional ele possui a razão que advém de Deus. Retomando a passagem de Gênesis, Lutero define o homem, ser racional como administrador na terra.

A preocupação de Lutero se demonstra em evidenciar a teologia da criação em face do viés antropocêntrico da filosofia da época que estava a separar a razão e a fé, não reconhecendo Deus como Deus criador. O homem só pode conhecer a si mesmo a partir de sua fonte: Deus. Noutro viés, Lutero evidencia a interface entre liberdade e homem: tal liberdade da condição do pecado proveniente da queda original somente é realizada no evento Cristo em que há a doação da eternidade.

A definição do homem alcança o seu sentido em Lutero a partir, especificamente, da sua compreensão da epístola paulina aos Romanos, tendo como base a doutrina da justificação mediante a fé. O homem é justificado através da fé sem as obras é a máxima que define a essência do homem, segundo Lutero. Tillich destaca a esse respeito: "nada justifica a não ser a fé [...] (TILLICH, 2000, p.243). As 95 teses em unidade com as 40 teses da "disputação" acerca do homem apontam para o sentido da Reforma em Lutero que implica também a reforma da compreensão do significado da "imagem de Deus" no homem. Lutero, portanto, busca contrapor as verdadeiras ideias filosóficas da 
época: o humanismo - embora, receba algum tipo de influência - e o aristotelismo.

\section{Considerações Finais}

Este artigo intitulado: "Religião e cultura: um diálogo teológico sobre a Reforma protestante a partir de Martinho Lutero e Paul Tillich" procurou apresentar algumas características relevantes sobre a Reforma protestante tendo como ponto de partida o pensamento teológico de Lutero e a análise do teólogo da cultura Tillich sobre tal acontecimento que marcou a história. Buscou-se refletir sobre alguns aspectos da Reforma considerando, especialmente, o cenário histórico em que ela irrompeu. Sobretudo, enfatizando a ação de Lutero ao inaugurar as 95 teses em 1517 enquanto uma ação revolucionária que veio a repercutir na própria compreensão da religião, da cultura, bem como, da fé.

A dimensão da fé no pensamento de Lutero destaca o princípio da justificação pela graça através da fé. Com isso, Lutero realiza a ruptura com o sistema romano, vindo a surgir uma nova religião: a religião protestante, ou seja, uma nova concepção sobre a comunhão do homem para com Deus. Lutero se volta para as Sagradas Escrituras buscando enfatizar que o centro da igreja e da existência mesma é Cristo. Ao se voltar para as Sagradas Escrituras, Lutero tem o propósito de destacar que o fundamento do relacionamento do homem para com Deus é a própria Palavra de Deus.

\section{Referências Bibliográficas}

www.statenvertaling.net : Home : Info, Domínio público, https://commons. wikimedia.org/w/index.php?curid $=4593502$

https://pt.wikipedia.org/wiki/Hieronymus_Bosch\#/media/Ficheiro:Last_judgement_Bosch.jpg

FERNANDES, M. A. "Disputação acerca do Homem (Teses)", de Martinho Lutero. Revista de Filosofia Moderna e Contemporânea, [S. 1.], v. 5, n. 2, p. 389-392, 2018. DOI: 10.26512/rfmc.v5i2.12615. Disponível em: https:// periodicos.unb.br/index.php/fmc/article/view/12615 Acesso em: 16 ago. 2021.

KANT, Immanuel. Textos seletos. Edição Bilíngue. Tradução de Raimundo Vier e Floriano de Sousa Fernandes. 2.ed. Petrópolis: Vozes, 1985. 
LUTERO, Martinho. Martinho Lutero: uma coletânea de escritos. Tradução de Johannes Bergmann, Arthur Wesley Dück e Valdemar Kroker. São Paulo: Vida Nova, 2017.

MONDIN, Battista. Curso de Filosofia. Vol. II. São Paulo: Paulinas. 1981.

REALE, Giovanni. História da filosofia: do humanismo a Descartes. v. 3. Tradução de Ivo Storniolo. São Paulo: Paulus, 2004.

RIBEIRO, Aline. Guia grandes mestres da pintura. 1. ed. São Paulo: OnLine, 2015.

TILLICH, Paul. Teologia Sistemática. Tradução Getúlio Bertelli e Geraldo Korndörfer. São Leopoldo: Sinodal, 2005.

Fonte Editorial, 2009.

. Teologia da cultura. Tradução: J. Maraschin. São Paulo, SP: . História do pensamento cristão. Tradução de Jaci Maraschin. 2.ed. São Paulo: ASTE, 2000.

Submetido em: 25-8-2021

Aceito em: 3-9-2021 